\title{
Barium isotopic composition of the mantle: Constraints from carbonatites
}

\author{
Wang-Ye Li ${ }^{\text {a,b, } *}$, Hui-Min Yu ${ }^{\text {a,b }}$, Juan Xu ${ }^{\text {a }}$, Ralf Halama ${ }^{c}$, Keith Bell ${ }^{\text {d }}$, \\ Xiao-Yun Nan ${ }^{\text {a }}$, Fang Huang a,b,*
}

${ }^{a}$ CAS Key Laboratory of Crust-Mantle Materials and Environments, School of Earth and Space Sciences, University of Science and Technology of China, Hefei, Anhui

$$
\text { 230026, China }
$$

${ }^{\mathrm{b}}$ CAS Center for Excellence in Comparative Planetology, Hefei, Anhui 230026, China

${ }^{\mathrm{c}}$ School of Geography, Geology and the Environment, Keele University, Keele,

Staffordshire, ST5 5BG, UK

d Department of Earth Sciences, Carleton University, 1125 Colonel By Drive, Ottawa, Ontario K1S 5B6, Canada

Text words: $\sim 3700$

Figures: 3

Tables: 3

Revised version submitted to GCA (June 12, 2019)

* Corresponding authors.

E-mail addresses: wyli@ustc.edu.cn (W.-Y. Li), fhuang@ustc.edu.cn (F. Huang). 


\section{Abstract}

8 nephelinites from Oldoinyo Lengai have similar $\delta^{137 / 134} \mathrm{Ba}$ values that range from

$9+0.01$ to $+0.03 \%$, indicating that $\mathrm{Ba}$ isotope fractionation during carbonatite

to explore the possibility of using carbonatites to constrain the $\mathrm{Ba}$ isotopic composition of the mantle, we report high-precision Ba isotopic analyses of: (1) carbonatites and associated silicate rocks from the only active carbonatite volcano, Oldoinyo Lengai, Tanzania, and (2) Archean to Cenozoic carbonatites from Canada, East Africa, Germany and Greenland. Carbonatites and associated phonolites and petrogenesis is negligible. The limited variation in $\delta^{137 / 134} \mathrm{Ba}$ values from -0.03 to $+0.09 \%$ for most carbonatite samples suggests that their mantle sources have a relatively homogeneous $\mathrm{Ba}$ isotopic composition. Based on the carbonatites investigated in this work, the average $\delta^{137 / 134} \mathrm{Ba}$ value of their mantle sources is estimated to be $+0.04 \pm 0.06 \%$ ( $2 \mathrm{SD}, n=16)$, which is similar to the average value of $+0.05 \pm 0.06 \%$ for mid-ocean ridge basalts. The lower $\delta^{137 / 134} \mathrm{Ba}$ value of $-0.08 \%$ in a Canadian sample and higher $\delta^{137 / 134} \mathrm{Ba}$ values of $+0.14 \%$ and $+0.23 \%$ in two Greenland samples suggest local mantle isotopic heterogeneity that may reflect the incorporation of recycled crustal materials in their sources.

$$
\text { Keywords: barium isotopes; carbonatites; mantle geochemistry; crustal recycling }
$$


$42=\left[\left({ }^{137 / 134} \mathrm{Ba}\right)_{\mathrm{sample}} /\left({ }^{137 / 134} \mathrm{Ba}\right)_{\mathrm{SRM} 3104 \mathrm{a}}-1\right] \times 1000$, where SRM3104a is a pure Ba

\section{Introduction}

Stable isotopes are powerful tools for identifying crustal recycling into the mantle, primarily due to significant stable isotope fractionation at low temperatures or near the Earth's surface (e.g., Hoefs, 2018). Recent studies have already explored mass-dependent isotopic variations for heavy metals ( $\mathrm{Fe}, \mathrm{Cu}, \mathrm{Mo}, \mathrm{Hg}, \mathrm{U}$ etc.) in different geochemical reservoirs and their use as geochemical tracers for a wide range of geological processes (see Teng et al., 2017). The Ba stable isotope system is potentially a sensitive tracer of crustal recycling because $\mathrm{Ba}$ is highly enriched in crustal rocks (average of $456 \mu \mathrm{g} / \mathrm{g}$ for the continental crust; Rudnick and Gao, 2014) and in pelagic and terrigenous marine sediments (average of $786 \mu \mathrm{g} / \mathrm{g}$ for the mean of global subducted sediments; Plank, 2014). By comparison, the depleted mantle (DM) and bulk silicate Earth (BSE) have average Ba contents of $1.2 \mu \mathrm{g} / \mathrm{g}$ (Salters and Stracke, 2004) and $7.0 \mu \mathrm{g} / \mathrm{g}$ (Sun and McDonough, 1989), respectively.

Barium has seven stable isotopes and the percent abundance of these isotopes is as follows: ${ }^{130} \mathrm{Ba}(0.11 \%),{ }^{132} \mathrm{Ba}(0.10 \%),{ }^{134} \mathrm{Ba}(2.42 \%),{ }^{135} \mathrm{Ba}(6.59 \%),{ }^{136} \mathrm{Ba}(7.85 \%)$, ${ }^{137} \mathrm{Ba}(11.23 \%)$, and ${ }^{138} \mathrm{Ba}(71.70 \%)$ (Eugster et al., 1969). Recent studies have demonstrated substantial $\mathrm{Ba}$ isotope fractionation among terrestrial samples and experimental precipitates (see review of Charbonnier et al., 2018). For example, measurements of granites, loess, glacial diamictites and river sediments show that the upper continental crust has highly variable $\delta^{137 / 134}$ BasRM3104a values ( $\delta^{137 / 134}$ BasRM3104a standard solution from NIST) ranging from -0.47 to $+0.35 \%$ (Nan et al., 2018), and 
negative values down to ca. $-0.5 \%$ were reported from marine/diagenetic barite (von Allmen et al., 2010). If Ba isotopes are to be used as possible tracers for crustal recycling, the $\mathrm{Ba}$ isotopic composition of the mantle reservoir needs to be defined. To our knowledge, no $\mathrm{Ba}$ isotopic data are currently available for mantle peridotites, and Ba isotopic data for mid-ocean ridge basalts (MORBs) have only recently been reported in a single paper, with $\delta^{137 / 134} \mathrm{Ba}$ values that range from $+0.02 \pm 0.03 \%$ to $+0.11 \pm 0.03 \%$ o (Nielsen et al., 2018). The $\delta^{138 / 134} \mathrm{Ba}$ values published by Nielsen et al. (2018) have been recalculated to enable comparison with the $\delta^{137 / 134} \mathrm{Ba}$ values used in this study, i.e. $\delta^{137 / 134} \mathrm{Ba}=0.75 \times \delta^{138 / 134} \mathrm{Ba}$ (Horner et al., 2015). Nielsen et al. (2018) speculated that the limited variability in Ba isotopic composition of MORBs reflects binary mixing between a "depleted MORB (D-MORB) mantle" with $\delta^{137 / 134} \mathrm{Ba}=$ $+0.11 \pm 0.02 \%$ and an "enriched MORB (E-MORB) mantle" with $\delta^{137 / 134} \mathrm{Ba}=+0.02$ $\pm 0.02 \%$, where the two end-member components were defined by the samples with the lowest ${ }^{87} \mathrm{Sr} /{ }^{86} \mathrm{Sr}(0.7023)$ and the highest ${ }^{87} \mathrm{Sr} /{ }^{86} \mathrm{Sr}(0.7034)$ ratios, respectively. However, D-MORBs with ${ }^{87} \mathrm{Sr} r{ }^{86} \mathrm{Sr}<0.7024$ display $\delta^{137 / 134} \mathrm{Ba}$ values from +0.02 to $+0.11 \%$, overlapping with the range from +0.02 to $+0.08 \%$ of E-MORBs with ${ }^{87} \mathrm{Sr} /{ }^{86} \mathrm{Sr}>0.7030$ (Nielsen et al., 2018). This feature suggests that the supposed $\mathrm{Ba}$ isotopic difference between the depleted mantle and enriched mantle may not actually exist.

In order to further investigate the $\mathrm{Ba}$ isotopic characteristics of the mantle, we focus on igneous carbonatites, i.e. mantle-derived rocks containing $>50 \%$ carbonate minerals. They are generated through low-degree partial melting of carbonated mantle, 
either as primitive melts or as parental carbonated silicate melts that undergo differentiation by liquid immiscibility and/or crystal fractionation (see reviews in Bell et al., 1998; Bizimis et al., 2003). Carbonatites can provide information on mantle geochemistry because: (1) they are widely distributed ( $>500$ occurrences on all continents) with ages ranging from 3 Ga to present (Woolley and Kjarsgaard, 2008), (2) their petrogenesis is now considered by some researches to be closely linked to the global carbon cycle (e.g., Barker, 1996; Hoernle et al., 2002), and (3) they are sensitive indicators of thermal instabilities because they are near-solidus melts and can be associated with dynamic processes in the mantle (e.g., orogenic activity or mantle upwelling including plumes/hot spots; Woolley and Kjarsgaard, 2008; Ernst and Bell, 2010). In terms of isotopes, the radiogenic isotopic data of most young carbonatites $(<200 \mathrm{Ma})$ plot within the fields of some ocean island basalts (OIBs), with values similar to the FOZO (focal zone), HIMU (high $\mu$, where $\mu={ }^{238} \mathrm{U} /{ }^{204} \mathrm{~Pb}$ ) and EM1 (enriched mantle type 1) mantle components based mainly on data from OIBs (Bell and Tilton, 2001). Mixing between two of these components, HIMU and EM1, characterizes many of the carbonatites from East Africa (Bell and Tilton, 2002; Bell and Simonetti, 2010). By contrast, the depleted MORB mantle (DMM) plays little role in forming carbonatites (see figures in Rukhlov et al., 2015). These observations are more consistent with a model involving the generation of carbonatite melts from sub-lithospheric mantle rather than the lithosphere (Bell and Simonetti, 2010). Both the traditional $\mathrm{C}$ and $\mathrm{O}$ stable isotopes (e.g., Deines, 1989; Keller and Hoefs, 1995; Ray et al., 1999) and the non-traditional Li and B stable isotopes 
(Halama et al., 2008; Hulett et al., 2016) have been analyzed in carbonatites to document isotopic variations of their mantle sources and to monitor their temporal evolution.

Carbonatites are ideal for investigating the $\mathrm{Ba}$ isotopic characteristics of the mantle because they contain very high abundances of $\mathrm{Ba}$ (generally hundreds to tens of thousands $\mu \mathrm{g} / \mathrm{g}$; e.g., Woolley and Kempe, 1989; Keller and Kraft, 1990). Moreover, the extremely low viscosity (e.g., Genge et al., 1995) leads to rapid migration of carbonatite melts to the surface, reducing the possible addition of $\mathrm{Ba}$ from crustal assimilation. In this work, high-precision Ba isotopic data were obtained of 19 well-characterized carbonatites. In addition, ten silicate rocks were analyzed from Oldoinyo Lengai. The purpose of this work is to illustrate the behaviour of $\mathrm{Ba}$ isotopes during carbonatite petrogenesis, and assess its significance in constraining the $\mathrm{Ba}$ isotopic composition of their mantle sources.

\section{Samples}

The carbonatite and associated silicate rock samples analyzed in this work are from Canada, East Africa, Germany and Greenland, with ages that range from the Archean to present. These samples have been well characterized with respect to petrological, major and trace element, and $\mathrm{Sr}-\mathrm{Nd}-\mathrm{Pb}-\mathrm{Li}-\mathrm{B}-\mathrm{C}-\mathrm{O}-\mathrm{Mg}$ isotopic aspects (Schleicher et al., 1990; Tilton and Bell,1994; Bell and Simonetti, 1996; Simonetti et al., 1997; Bell and Tilton, 2001; Halama et al., 2005, 2007, 2008; Klaudius and Keller, 2006; Rukhlov et al., 2015; Hulett et al., 2016; Li et al., 2016). Similar to the majority 
of global carbonatites, the carbonatite samples studied here have $\mathrm{Sr}-\mathrm{Nd}$ isotopic compositions similar to those of OIBs (Halama et al., 2008). Most of the samples have oxygen isotopic compositions that fall into the range of "primary" igneous carbonatites, although some samples show elevated $\delta^{18} \mathrm{O}$ values, which are common post-emplacement features in altered carbonatites (Demény et al., 2004). The detailed petrological and geochemical features of the samples have been presented in previous literature (Halama et al., 2007, 2008, and references therein), and only a brief introduction about the samples is given here.

\subsection{The 0 Ma carbonatites and silicate rocks from Oldoinyo Lengai, Tanzania}

As Oldoinyo Lengai is the only active carbonatite volcano on Earth, it has played a key role in assessing the origin of carbonatite melts (see Bell and Keller, 1995). The generally accepted model for natrocarbonatite petrogenesis at Oldoinyo Lengai involves silicate-carbonatite immiscible separation from a parental carbonated, alkaline silicate melt (e.g., Freestone and Hamilton, 1980; Church and Jones, 1995; Keller and Spettel, 1995; Dawson, 1998; Brooker and Kjarsgaard, 2011). Additional magmatic processes described at Oldoinyo Lengai include fractional crystallization of carbonate minerals nyerereite $\left[\mathrm{Na}_{2} \mathrm{Ca}\left(\mathrm{CO}_{3}\right)_{2}\right]$ and gregoryite $\left[\left(\mathrm{Na}_{2}, \mathrm{~K}_{2}, \mathrm{Ca}\right) \mathrm{CO}_{3}\right]$ (e.g., Peterson, 1990; Gittins and Jago, 1998) as well as phenocryst assimilation and cumulate disruption (Mitchell and Dawson, 2012). Differentiation via carbonate-halide liquid immiscibility may also have occurred during eruption (Potter et al., 2017). 

relationship of silicate rocks and natrocarbonatites from each unit. Stratigraphic relationships and $\mathrm{Sr}-\mathrm{Nd}-\mathrm{Pb}$ isotopic data suggest that the combeite-wollastonite nephelinites (CWNs) and natrocarbonatites of Lengai II B are conjugate silicate and carbonatite melts produced by liquid immiscibility, unlike the phonolites of Lengai I and CWNs of Lengai II A (Klaudius and Keller, 2006). Samples studied here include: 1) natrocarbonatites (OL2, OL7, OL123, OL148 and OL259) and the petrogenetically related CWNs (OL624, OL788 and OL804) from the Lengai II B unit, and 2) silicate rocks not generated by liquid immiscibility (including phonolites OL440, OL442, compositions of these two types of silicate rocks can provide constraints on the behaviour of $\mathrm{Ba}$ isotopes during the generation of conjugate liquids.

\section{Greenland}

The Archean carbonatite samples from the Dolodau and Lac Shorrt occurrences in 
amphibole-biotite silicocarbonatite (DOD91). Proterozoic carbonatite samples from the Gardar igneous province, South Greenland, are calcite carbonatites (GR46, GR73 and GR74) from the Grønnedal-Ika complex (1.3 Ga). Phanerozoic carbonatite samples consist of a calcite carbonatite sample (K5) from the 17 Ma old Kaiserstuhl complex, Germany, and carbonatites with ages ranging from 138 to 13 Ma from the East African Rift (calcite carbonatites N1295, PH212, PH213, SU103 and HB, and a ferrocarbonatite DU365).

The 29 whole-rock samples investigated here for Ba isotopic compositions are the same powders as those studied previously for radiogenic and $\mathrm{Li}-\mathrm{C}-\mathrm{O}$ isotopic compositions (Halama et al., 2007, 2008, and references therein) as well as $\mathrm{Mg}$ isotopic compositions but only for the Oldoinyo Lengai samples (Li et al., 2016). On the basis of petrography and Li-C-O-Mg isotopic data (Halama et al., 2007, 2008; Li et al., 2016), post-emplacement alteration is negligible for all but three of the carbonatite samples from East Africa (i.e., N1295, DU365 and OL804). These three samples show signs of late-stage alteration (e.g., altered minerals or hydrothermal veins), and two of them (N1295 and DU365) have elevated $\delta^{18} \mathrm{O}$ values (12.4\% and $15.6 \%$ ) that lie outside the range of "primary" igneous carbonatites (see Fig. 5a in Halama et al., 2008).

\section{Analytical methods}

Barium isotopic analyses were performed at the University of Science and Technology of China, Hefei. All chemical procedures were carried out in an ISO-class 
176

177

6 clean laboratory. Using screw-top Teflon beakers, the whole-rock powders were dissolved in a combination of concentrated $\mathrm{HF}-\mathrm{HNO}_{3}-\mathrm{HCl}$. Purification of $\mathrm{Ba}$ was achieved by cation exchange chromatography with Bio-Rad 200-400 mesh AG50W-X12 resin, following established procedures (Nan et al., 2015, 2018). Sample solutions containing $\sim 2 \mu \mathrm{g}$ Ba were loaded onto the resin. The Ba recoveries through column chemistry, based on analyses of Ba content in the elution collected before and after the Ba cut, were $>99 \%$. The procedural blank was $2 \mathrm{ng} \mathrm{Ba}$.

Barium isotopic measurements were carried out on a Neptune Plus multi-collector inductively coupled plasma mass spectrometer (MC-ICP-MS), and a double-spike technique was used to correct for instrumental mass bias. An appropriate amount of the ${ }^{135} \mathrm{Ba}-{ }^{136} \mathrm{Ba}$ double spike with a ratio of $1.72(\mathrm{~m} / \mathrm{m}$; Rudge et al., 2009) was added to a portion of the purified sample solution containing $\sim 100 \mathrm{ng} \mathrm{Ba}$. The optimal range of the proportion of double spike in the double spike-sample mixture is 0.43 to 0.60 . The "dry" plasma conditions (Aridus II desolvating nebulizer) were used to increase sensitivity $\left(\sim 7 \mathrm{~V} / 100 \mathrm{ng} / \mathrm{g}\right.$ for $\left.{ }^{137} \mathrm{Ba}\right)$. Barium isotopic analyses were conducted in a low-resolution mode, with ${ }^{134} \mathrm{Ba},{ }^{135} \mathrm{Ba},{ }^{136} \mathrm{Ba}$ and ${ }^{137} \mathrm{Ba}$ collected simultaneously by the L2, L1, C and H1 Faraday cups, respectively. ${ }^{131} \mathrm{Xe}$ and ${ }^{140} \mathrm{Ce}$ were also collected by the L4 and H3 Faraday cups to correct the effects of isobaric interferences from Xe and Ce. The background signals for ${ }^{137} \mathrm{Ba}(<0.005 \mathrm{~V})$ were negligible relative to the sample signals $(\sim 7 \mathrm{~V})$.

The results are reported in $\delta^{137 / 134} \mathrm{Ba}$ values relative to the NIST Standard Reference Material (SRM) 3104a, i.e. $\delta^{137 / 134} \mathrm{Ba}=\left[\left({ }^{137 / 134} \mathrm{Ba}\right)_{\text {sample }} /\left({ }^{137 / 134} \mathrm{Ba}\right)_{\mathrm{SRM} 3104 \mathrm{a}}-\right.$ 
198

199

200

201

202

203

204

205

206

207

208

209

210

211

212

213

214

215

216

217

218

219

$1] \times 1000$. For comparison, all published $\delta^{138 / 134} \mathrm{Ba}$ values have been recalculated to $\delta^{137 / 134} \mathrm{Ba}$ values by assuming mass-dependent fractionation following $\delta^{137 / 134} \mathrm{Ba}=$ $0.75 \times \delta^{138 / 134} \mathrm{Ba}$ (Horner et al., 2015). Based on duplicate analyses of two in-house reference solutions USTC-Ba and ICPUS-Ba, the external precision is $\leq 0.04 \%$ o for $\delta^{137 / 134} \mathrm{Ba}(2 \mathrm{SD})$. The $\delta^{137 / 134} \mathrm{Ba}$ values yielded in this study for the three USGS reference materials, i.e. BCR-2, BHVO-2 and COQ-1, are in good agreement with previously published values (Table 1).

\section{Results}

Barium isotopic compositions are reported in Table 2 for the 0 Ma carbonatites and silicate rocks from Oldoinyo Lengai (OL), and in Table 3 for Archean to Cenozoic carbonatites. For reference, $\mathrm{Ba}$ concentrations of all samples and $\mathrm{Mg}$ isotopic compositions of the OL samples that have been reported in previous studies (Simonetti et al., 1997; Klaudius and Keller, 2006; Halama et al., 2008; Li et al., 2016) are also included in Tables 2 and 3.

Due to the high incompatibility of Ba during mantle melting $\left(\mathrm{D}^{\text {solid/melt }}=0.00012\right.$; Workman and Hart, 2005), preferential partition of $\mathrm{Ba}$ into the carbonatite melt during liquid immiscibility (e.g., $\mathrm{D}^{\text {carbonatite liquid/silicate liquid }}=5.2$; Veksler et al., 1998), and different degrees of enrichment or depletion of $\mathrm{Ba}$ during magmatic crystallization, the $\mathrm{Ba}$ concentrations of carbonatites investigated here vary considerably over more than two orders of magnitude (Fig. 1). However, regardless of their highly variable Ba concentrations, different localities and different ages, 17 of the 19 carbonatite samples 
display $\delta^{137 / 134} \mathrm{Ba}$ values that range from -0.03 to $+0.14 \%$, which are similar, within limits of analytical uncertainties, to the range of MORBs that extends from -0.01 to $+0.14 \%$ o (Nielsen et al., 2018; Fig. 1). The remaining two samples are outside the range of MORBs (Fig. 1), i.e., one carbonatite from Canada (DOD 91) with a lower $\delta^{137 / 134} \mathrm{Ba}$ value of $-0.08 \%$ and one carbonatite from Greenland (GR74) with a higher $\delta^{137 / 134} \mathrm{Ba}$ value of $+0.23 \%$. The OL silicate rocks have homogeneous $\delta^{137 / 134} \mathrm{Ba}$ values from +0.01 to $+0.03 \%$ with an average of $+0.02 \pm 0.02 \%$ ( $2 \mathrm{SD}, n=10)$, which is identical to that of the OL carbonatites $(+0.02 \pm 0.02 \%, 2 \mathrm{SD}, n=5)$.

\section{Discussion}

\subsection{The behaviour of $\mathrm{Ba}$ isotopes during carbonatite petrogenesis}

Oldoinyo Lengai has been the subject of many studies and most believe that the natrocarbonatites were formed by liquid immiscibility involving a parental peralkaline silicate melt at low pressures (e.g., Freestone and Hamilton, 1980; Church and Jones, 1995; Keller and Spettel, 1995; Dawson, 1998; Brooker and Kjarsgaard, 2011). Li et al. (2016) demonstrated that the OL silicate rocks not generated by immiscibility have mantle-like $\mathrm{Mg}$ isotopic compositions, whereas those related to carbonatites by liquid immiscibility have isotopically heavier Mg (Fig. 2a). Such a difference indicates significant $\mathrm{Mg}$ isotope fractionation during liquid immiscibility, with heavy $\mathrm{Mg}$ isotopes preferentially partitioning into the silicate melts. By contrast, all of the OL silicate rocks analyzed here have homogeneous $\delta^{137 / 134} \mathrm{Ba}$ values that range from +0.01 to $+0.03 \%$, all within the limits of analytical uncertainty (Fig. 2a). In addition, 
there is no correlation between the $\delta^{137 / 134} \mathrm{Ba}$ values and the index of carbonatite magma differentiation marked by a decrease in $\mathrm{CaO}$ contents (Gittins and Jago, 1998;

Fig. 2b). These findings suggest that even during the complex petrogenetic processes associated with the Oldoinyo Lengai magmatism, such as liquid immiscibility and crystal fractionation, little $\mathrm{Ba}$ isotope fractionation has taken place. The exact mechanism for the different behaviour of $\mathrm{Mg}$ and $\mathrm{Ba}$ isotopes during carbonatite magmatism is currently unclear, but may simply result from the smaller relative mass difference between ${ }^{137} \mathrm{Ba}$ and ${ }^{134} \mathrm{Ba}$ (ca. $2 \%$ ) than that between ${ }^{26} \mathrm{Mg}$ and ${ }^{24} \mathrm{Mg}$ (ca. $8 \%)$.

In addition, because $\mathrm{Ba}$ is highly incompatible with an estimated bulk distribution coefficient $\mathrm{D}^{\text {solid/melt }}$ of 0.00012 during mantle melting (Workman and Hart, 2005), $\sim 99 \%$ of the $\mathrm{Ba}$ will enter into the melt after $1 \%$ partial melting, implying that the $\mathrm{Ba}$ isotopic composition of any partial melts from the mantle, including carbonatitic melts, should reflect the source composition (Nielsen et al., 2018). It thus appears that $\mathrm{Ba}$ isotopes remain relatively unaffected during both partial melting and liquid immiscibility, even though the Ba concentrations will be significantly changed during these processes.

\subsection{Barium isotopic composition of the mantle}

The similarity in $\delta^{137 / 134} \mathrm{Ba}$ values of most carbonatites investigated here to those of MORBs (Fig. 1) suggests that the mantle sources for both have a relatively homogeneous $\mathrm{Ba}$ isotopic composition. In order to estimate the average $\delta^{137 / 134} \mathrm{Ba}$ 
value of the mantle sources of carbonatites, the outliers, if any, are identified through statistical analysis. Using the box plot method (see NIST/SEMATECH e-Handbook of Statistical Methods), three samples, i.e., DOD91, GR73 and GR74, are identified as outliers (Fig. 3a).

Based on our data set, the average $\delta^{137 / 134} \mathrm{Ba}$ value of the mantle sources of the parental melts to carbonatites is estimated to be $+0.04 \pm 0.06 \%$ ( $2 \mathrm{SD}, n=16$; Fig. $3 \mathrm{a}$ ) when the three outliers are excluded. Hence, within current analytical uncertainties, the average $\delta^{137 / 134} \mathrm{Ba}$ value of carbonatites is indistinguishable from that of $+0.05 \pm$ 0.06\% for MORBs (recalculated from Nielsen et al., 2018; Fig. 3b). This is in contrast to the difference in radiogenic isotopic compositions between MORBs and carbonatites (see figures in Rukhlov et al., 2015). The radiogenic isotopic characteristics of some carbonatites are more closely related to those of some OIBs (Bell and Tilton, 2002; Bell and Simonetti, 2010). A similarity may also exist for the Ba isotope system between carbonatites and OIBs, for which an average $\delta^{137 / 134} \mathrm{Ba}$ value of $0.02 \pm 0.10 \%$ has been reported by Huang et al. (2015). Collectively, it seems that the mantle sources for the parental melts of MORBs, OIBs and carbonatites may be relatively homogeneous in terms of $\mathrm{Ba}$ isotopic compositions. Such a characteristic implies that the terrestrial differentiation events that generated the depleted and enriched mantle reservoirs (i.e., a major differentiation event during the Hadean recorded by the Nd-Hf isotopes and a second one at $\sim 3$ Ga recorded by the Sr-Pb isotopes; Bell and Tilton, 2002; Rukhlov et al., 2015) may not have affected the Ba isotope system. 

present-day carbonatites investigated here overlap the range typical for modern mantle-derived rocks (MORBs and OIBs). If the mantle sources of carbonatites are related to subduction and recycling of oceanic lithosphere, as suggested by some studies (Nelson et al., 1988; Hoernle et al., 2002; Hulett et al., 2016), we see no evidence for this in terms of their Ba isotopic composition. This implies that one or

292 both of the following is true: (1) the bulk Ba isotopic composition of subducted materials does not deviate greatly from the average mantle value and/or (2) subducted crustal $\mathrm{Ba}$ is effectively homogenized upon subduction into the mantle. The first possibility is in agreement with the observations that the average $\mathrm{Ba}$ isotopic 296 compositions of marine sediments $\left(\delta^{137 / 134} \mathrm{Ba}=+0.03 \%\right)$ and altered oceanic crust (Fig. 3). there are three outliers (i.e., DOD91, GR73 and GR74; Fig. 3a). Their distinct $\delta^{137 / 134} \mathrm{Ba}$ values may not result from surface alteration because these three samples lack petrographic evidence for alteration and have Li-C-O isotopic compositions similar to those of "primary" igneous carbonatites (Halama et al., 2008). In addition, crustal contamination also seems unlikely because of the extremely low viscosity of carbonatite melts (e.g., Genge et al., 1995). We therefore attribute the variable Ba 
isotopic compositions of the three carbonatites from Canada and Greenland to local heterogeneities in the mantle.

Isotopic heterogeneity within the mantle is usually related to recycling of oceanic crustal materials (e.g., Hofmann, 2014). Although the data base is relatively small, available data show that marine sediments and altered oceanic crust (AOC) have variable $\delta^{137 / 134} \mathrm{Ba}$ values that range from -0.08 to $+0.15 \%$ and from -0.07 to $+0.25 \%$, respectively (Fig. 3b; Bridgestock et al., 2018, 2019; Nielsen et al., 2018). An even larger $\delta^{137 / 134} \mathrm{Ba}$ variation from -0.17 to $+0.30 \%$ for $\mathrm{AOC}$ has been reported by Nan et al. (2017), and higher $\delta^{137 / 134} \mathrm{Ba}$ values than those presently observed in marine sediments could be expected as suspended particles in seawater display high $\delta^{137 / 134} \mathrm{Ba}$ values ranging from +0.19 to $+0.45 \%$ (Horner et al., 2015; Cao et al., 2016). Hence, incorporation of recycled marine sediments and/or AOC with extreme Ba isotopic compositions in local parts of the mantle might account for the distinct $\delta^{137 / 134} \mathrm{Ba}$ values of the three outlier carbonatites from Canada and Greenland. If this is true, $\mathrm{Ba}$ isotopes could potentially be a novel tracer of crustal recycling. However, further work is needed to find out an unequivocal explanation of the observed different $\mathrm{Ba}$ isotopic composition (Fig. 3a) but similar Li-C-O isotopic compositions (Halama et al., 2008) between the three outliers and the other carbonatites investigated in this study.

\section{Conclusions}

The main conclusions from this study are: 
(1) Carbonatites and associated silicate rocks from Oldoinyo Lengai have homogeneous $\delta^{137 / 134} \mathrm{Ba}$ values that range from +0.01 to $+0.03 \%$, indicating insignificant $\mathrm{Ba}$ isotope fractionation during both silicate-carbonatite liquid immiscibility and subsequent magma differentiation. Hence, Ba isotopic composition of carbonatites could reflect that of their mantle sources.

(2) Most carbonatites from Canada, East Africa, Germany and Greenland display a limited variation in $\delta^{137 / 134} \mathrm{Ba}$ values ranging from -0.03 to $+0.09 \%$, suggesting that the mantle sources of carbonatites have a relatively homogeneous $\mathrm{Ba}$ isotopic composition. The spatial distribution of the 16 carbonatites we have measured suggests that their mantle sources have an average $\delta^{137 / 134} \mathrm{Ba}$ value of $+0.04 \pm 0.06 \%$ o (2SD), similar to those of MORBs and OIBs. Therefore, the mantle sources for the parental melts of MORBs, OIBs and carbonatites are likely to be relatively homogeneous in terms of $\mathrm{Ba}$ isotopic compositions.

(3) The distinct $\delta^{137 / 134} \mathrm{Ba}$ values of the three outlier carbonatites might reflect the incorporation of marine sediments and/or altered oceanic crust with extreme $\mathrm{Ba}$ isotopic compositions in their mantle sources. On the basis of these observations, $\mathrm{Ba}$ isotopes may potentially be a novel tracer of crustal recycling.

\section{Acknowledgments}

We thank J. Keller and J. Klaudius for sharing samples. The constructive comments from three anonymous reviewers and efficient handling from the editor Fang-Zhen Teng are greatly appreciated. This work is financially supported by the 
352

353

354

355

356

357

358

359

360

361

362

363

364

365

366

367

368

369

370

371

372

373

National Natural Science Foundation of China (41573002, 41873005, 41630206) and by the Natural Sciences and Engineering Research Council of Canada.

\section{References}

Barker D. S. (1996) Consequences of recycled carbon in carbonatites. Can. Mineral. 34, 373-387.

Bell K. and Keller J. (1995) Carbonatite Volcanism: Oldoinyo Lengai and the Petrogenesis of Natrocarbonatites. IAVECI Proceedings in Volcanology 4. Springer-Verlag, Berlin. 210p.

Bell K. and Simonetti A. (1996) Carbonatite magnetism and plume activity: implications from the $\mathrm{Nd}, \mathrm{Pb}$ and $\mathrm{Sr}$ isotope systematics of Oldoinyo Lengai. $J$. Petrol. 37, 1321-1339.

Bell K, Kjarsgaard B. A. and Simonetti A. (1998) Carbonatites - into the twenty-first century. J. Petrol. 39, 1839-1845.

Bell K. and Tilton G. R. (2001) Nd, Pb and Sr isotopic compositions of East African Carbonatites: evidence for mantle mixing and plume inhomogeneity. J. Petrol. 42, $1927-1945$.

Bell K. and Tilton G. R. (2002) Probing the mantle: the story from carbonatites. EOS Transactions, $A G U$ 83, 273, 276-277.

Bell K. and Simonetti A. (2010) Source of parental melts to carbonatites - critical isotopic constraints. Miner. Petrol. 98, 77-89. 
Bizimis M., Salters V. J. M. and Dawson J. B. (2003) The brevity of carbonatite sources in the mantle: evidence from Hf isotopes. Contrib. Mineral. Petrol. 145, $281-300$.

Bridgestock L., Hsieh Y.-T., Porcelli D., Homoky W. B., Bryan A. and Henderson G. M. (2018) Controls on the barium isotope compositions of marine sediments. Earth Planet. Sci. Lett. 481, 101-110.

Bridgestock L., Hsieh Y.-T., Porcelli D. and Henderson G. M. (2019) Increased export production during recovery from the Paleocene-Eocene thermal maximum constrained by sedimentary Ba isotopes. Earth Planet. Sci. Lett. 510, 53-63.

Brooker R. A. and Kjarsgaard B. A. (2011) Silicate-carbonate liquid immiscibility and phase relations in the system $\mathrm{SiO}_{2}-\mathrm{Na}_{2} \mathrm{O}-\mathrm{Al}_{2} \mathrm{O}_{3}-\mathrm{CaO}-\mathrm{CO}_{2}$ at $0.1-2.5 \mathrm{GPa}$ with application to carbonatite genesis. J. Petrol. 52, 1281-1305.

Bullen T. and Chadwick O. (2016) Ca, Sr and Ba stable isotopes reveal the fate of soil nutrients along a tropical climosequence in Hawaii. Chem. Geol. 422, 25-45.

Cao Z., Siebert C., Hathorne E. C., Dai M. and Frank M. (2016) Constraining the oceanic barium cycle with stable barium isotopes. Earth Planet. Sci. Lett. 434, $1-9$.

Charbonnier Q., Moynier F. and Bouchez J. (2018) Barium isotope cosmochemistry and geochemistry. Sci. Bull. 63, 385-394.

Church A. A. and Jones A. P. (1995) Silicate-carbonate immiscibility at Oldoinyo Lengai. J. Petrol. 36, 869-889. 
Dawson J. B. (1998) Peralkaline nephelinite-natrocarbonatite relationships at Oldoinyo Lengai, Tanzania. J. Petrol. 39, 2077-2094.

Deines P. (1989) Stable isotope variations in carbonatites. In Carbonatites: Genesis and Evolution (ed. K. Bell). Unwin Hyman, London. pp. 301-359.

Demény A., Sitnikova, M. A. and Karchevsky P. I. (2004) Stable C and O isotope 400 compositions of carbonatite complexes of the Kola Alkaline Province: phoscorite-carbonatite relationships and source compositions. In Phoscorites and Carbonatites from Mantle to Mine: the Key Example of the Kola Alkaline Province (eds. F. Wall and A. N. Zaitsev). The Mineralogical Society Series 10, pp. $407-431$.

Ernst R. E. and Bell K. (2010) Large igneous provinces (LIPs) and carbonatites. Miner. Petrol. 98, 55-76.

Eugster O., Tera F. and Wasserburg G. J. (1969) Isotopic analyses of barium in meteorites and in terrestrial samples. J. Geophys. Res. 74, 3897-3908.

Freestone I. C. and Hamilton D. L. (1980) The role of liquid immiscibility in the genesis of carbonatites - An experimental study. Contrib. Mineral. Petrol. 73, $105-117$.

Genge M. J., Price G. D. and Jones A. P. (1995) Molecular dynamics simulation of $\mathrm{CaCO}_{3}$ melts to mantle pressures and temperatures: implications for carbonatite magmas. Earth Planet. Sci. Lett. 131, 225-238.

Gittins J. and Jago B. C. (1998) Differentiation of natrocarbonatite magma at Oldoinyo Lengai volcano, Tanzania. Mineral. Mag. 62, 759-768. 
Halama R., Vennemann T. W., Siebel W. and Markl G. (2005) The Grønnedal-Ika carbonatite-syenite complex, South Greenland: carbonatite formation by liquid immiscibility. J. Petrol. 46, 191-217.

Halama R., McDonough W. F., Rudnick R. L., Keller J. and Klaudius J. (2007) The Li isotopic composition of Oldoinyo Lengai: nature of the mantle sources and lack of isotopic fractionation during carbonatite petrogenesis. Earth Planet. Sci. Lett. 254, $77-89$.

Halama R., McDonough W. F., Rudnick R. L. and Bell K. (2008) Tracking the lithium isotopic evolution of the mantle using carbonatites. Earth Planet. Sci. Lett. 265, $726-742$.

Hoefs J. (2018) Stable isotope geochemistry (eighth edition). Springer, Berlin. 437p.

Hoernle K., Tilton G., Le Bas M. J., Duggen S. and Garbe-Schönberg D. (2002) Geochemistry of oceanic carbonatites compared with continental carbonatites: mantle recycling of oceanic crustal carbonate. Contrib. Mineral. Petrol. 142, $520-542$.

Hofmann A. W. (2014) Sampling mantle heterogeneity through oceanic basalts: isotopes and trace element. In Treatise on Geochemistry, vol. 3, The mantle and core (second ed.) (ed. R.W. Carlson). Elsevier, Oxford. pp. 67-101.

Horner T. J., Kinsley C. W. and Nielsen S. G. (2015) Barium-isotopic fractionation in seawater mediated by barite cycling and oceanic circulation. Earth Planet. Sci. Lett. 430, 511-522. 
Huang F., Nan X.-Y., Yu H.-M., Huang S.-C. and Huang J. (2015) Barium isotope compositions of igneous rocks. Goldschmidt Abstr. 1331.

Hulett S. R. W., Simonetti A., Rasbury E. T. and Hemming N. G. (2016) Recycling of subducted crustal components into carbonatite melts revealed by boron isotopes. Nat. Geosci. 9, 904-909.

Keller J. and Kraft M. (1990) Effusive natrocarbonatite activity of Oldoinyo Lengai, June 1988. Bull. Volcanol. 52, 629-645.

Keller J. and Hoefs J. (1995) Stable isotope characteristics of recent natrocarbonatites from Oldoinyo Lengai. In Carbonatite Volcanism: Oldoinyo Lengai and the Petrogenesis of Natrocarbonatites (eds. K. Bell and J. Keller). Springer-Verlag, Berlin. pp. 113-123.

Keller J. and Spettel B. (1995) The trace element composition and petrogenesis of natrocarbonatites. In Carbonatite volcanism: Oldoinyo Lengai and the Petrogenesis of Natrocarbonatite (eds. K. Bell and J. Keller). Springer-Verlag, Berlin. pp. 70-86.

Klaudius J. and Keller J. (2006) Peralkaline silicate lavas at Oldoinyo Lengai, Tanzania. Lithos 91, 173-190.

Li W.-Y., Teng F.-Z., Halama R., Keller J. and Klaudius J. (2016) Magnesium isotope fractionation during carbonatite magmatism at Oldoinyo Lengai, Tanzania. Earth Planet. Sci. Lett. 444, 26-33. 
Mitchell R. H. and Dawson J. B. (2012) Carbonate-silicate immiscibility and extremely peralkaline silicate glasses from Nasira cone and recent eruptions at Oldoinyo Lengai Volcano, Tanzania. Lithos 152, 40-46.

Nan X., Wu F., Zhang Z., Hou Z., Huang F. and Yu H. (2015) High-precision barium isotope measurements by MC-ICP-MS. J. Anal. At. Spectrom. 30, 2307-2315.

Nan X., Yu H. and Gao Y. (2017) Barium isotope composition of altered oceanic crust from IODP Site 1256 at the East Pacific Rise. AGU Abstr. V33C-0534.

Nan X.-Y., Yu H.-M., Rudnick R. L., Gaschnig R. M., Xu J., Li W.-Y., Zhang Q., Jin Z.-D., Li X.-H. and Huang F. (2018) Barium isotopic composition of the upper continental crust. Geochim. Cosmochim. Acta 233, 33-49.

Nelson D. R., Chivas A. R., Chappell B. W. and McCulloch M. T. (1988) Geochemical and isotopic systematics in carbonatites and implications for the evolution of ocean-island sources. Geochim. Cosmochim. Acta 52, 1-17.

Nielsen S. G., Horner T. J., Pryer H. V., Blusztajn J., Shu Y., Kurz M. D. and Le Roux V. (2018) Barium isotope evidence for pervasive sediment recycling in the upper mantle. Sci. $A d v .4$, eaas 8675 .

NIST/SEMATECH e-Handbook of Statistical Methods. The chapter 7.1.6. What are outliers in the data? https://www.itl.nist.gov/div898/handbook/prc/section1/prc16.htm.

Peterson T. D. (1990) Petrology and genesis of natrocarbonatite. Contrib. Mineral. Petrol. 105, 143-155. 
Plank T. (2014) The chemical composition of subducting sediments. In Treatise on Geochemistry, vol. 4, The crust (second ed.) (ed. R. L. Rundick). Elsevier, Oxford. pp. 607-629.

Potter N. J., Kamenetsky V. S., Simonetti A. and Goemann K. (2017) Different types of liquid immiscibility in carbonatite magmas: A case study of the Oldoinyo Lengai 1993 lava and melt inclusions. Chem. Geol. 455, 376-384.

Ray J. S., Ramesh R. and Pande K. (1999) Carbon isotopes in Kerguelen plume-derived carbonatites: evidence for recycled inorganic carbon. Earth Planet. Sci. Lett. 170, 205-214.

Rudge J. F., Reynolds B. C. and Bourdon B. (2009) The double spike toolbox. Chem. Geol. 265, 420-431.

Rudnick R. L. and Gao S. (2014) Composition of the continental crust. In Treatise on Geochemistry, vol. 4, The crust (second ed.) (ed. R. L. Rundick). Elsevier, Oxford. pp. $1-51$.

Rukhlov A. S., Bell K. and Amelin Y. (2015) Carbonatites, isotopes and evolution of the subcontinental mantle: An overview. In Symposium on Strategic and Critical Materials Proceedings (eds. G. J. Simandl and M. Neetz). British Columbia Geological Survey Paper 2015-3. pp. 39-64.

Salters V. J. M. and Stracke A. (2004) Composition of the depleted mantle. Geochem. Geophys. Geosyst. 5, Q05B07, doi:10.1029/2003GC000597. 
Schleicher H., Keller J. and Kramm U. (1990) Isotope studies on alkaline volcanics and carbonatites from the Kaisertuhl, Federal Republic of Germany. Lithos 26, $21-35$.

Simonetti A., Bell K. and Shrady C. (1997) Trace- and rare-earth-element geochemistry of the June 1993 natrocarbonatite lavas, Oldoinyo Lengai (Tanzania): implications for the origin of carbonatite magmas. J. Volcanol. Geotherm. Res. 75, 89-106.

Sun S.-S. and McDonough W. F. (1989) Chemical and isotopic systematics of oceanic basalts: implications for mantle composition and processes. In Magmatism in the Ocean Basins (eds. A. D. Saunders and M. J. Norry). Geological Society, London. pp. 313-345.

Teng F.-Z., Watkins J. and Dauphas N. (2017) Non-traditional stable isotopes. Rev. Mineral. Geochem. 82, 885p.

Tilton G. R. and Bell K. (1994) Sr-Nd-Pb isotope relationship in Late Archean carbonatites and alkaline complexes: applications to the geochemical evolution of Archean mantle. Geochim. Cosmochim. Acta 58, 3145-3154.

Veksler I. V., Petibon C., Jenner G. A., Dorfman A. M. and Dingwell D. B. (1998) Trace element partitioning in immiscible silicate-carbonate liquid systems: an initial experimental study using a centrifuge autoclave. J. Petrol. 39, 2095-2104.

von Allmen K., Böttcher M. E., Samankassou E. and Nägler T. F. (2010) Barium isotope fractionation in the global barium cycle: First evidence from barium minerals and precipitation experiments. Chem. Geol. 277, 70-77. 
Woolley A. R. and Kempe D. R. C. (1989) Carbonatites: Nomenclature, average chemical compositions and element distribution. In Carbonatites: Genesis and Evolution (ed. K. Bell). Unwin Hyman, London. pp. 1-14.

Woolley A. R. and Kjarsgaard B. A. (2008) Carbonatite occurrences of the world: map and database. Geol. Surv. Can. Open File 5796, 10.4095/225115.

Workman R. K. and Hart S. R. (2005) Major and trace element composition of the depleted MORB mantle (DMM). Earth Planet. Sci. Lett. 231, 53-72.

Zeng Z., Li X., Liu Y., Huang F. and Yu H.-M. (2019) High-precision barium isotope measurements of carbonates by MC-ICP-MS. Geostand. Geoanal. Res. 43, 291-300. 
532 Barium isotopic compositions of reference materials

\begin{tabular}{|c|c|c|c|c|}
\hline Standard & Description & $\delta^{137 / 134} \mathrm{Ba}(\%)$ & $2 \mathrm{SD}(\%)^{\mathrm{a}}$ & Reference \\
\hline BCR-2 & Basalt, Columbia & +0.02 & 0.03 & \\
\hline Duplicate $^{\mathrm{b}}$ & River, USA & +0.06 & 0.03 & \\
\hline Duplicate & & +0.05 & 0.04 & \\
\hline Duplicate & & +0.04 & 0.03 & \\
\hline Duplicate & & +0.02 & 0.04 & \\
\hline \multirow[t]{3}{*}{ Average } & $(n=5)$ & +0.04 & 0.04 & This study \\
\hline & & +0.05 & 0.04 & Nan et al. (2015) \\
\hline & & +0.05 & 0.03 & Nan et al. (2018) \\
\hline BHVO-2 & Basalt, Hawaii, USA & +0.01 & 0.03 & \\
\hline Duplicate & & +0.04 & 0.03 & \\
\hline Duplicate & & +0.02 & 0.04 & \\
\hline \multirow[t]{3}{*}{ Average } & $(n=3)$ & +0.02 & 0.03 & This study \\
\hline & & +0.05 & 0.03 & Nan et al. (2015) \\
\hline & & +0.05 & 0.04 & Bullen and Chadwich (2016) \\
\hline COQ-1 & Carbonatite, $\mathrm{Oka}$ & +0.06 & 0.03 & \\
\hline Duplicate & complex, Canada & +0.08 & 0.03 & \\
\hline Duplicate & & +0.07 & 0.04 & \\
\hline Duplicate & & +0.07 & 0.04 & \\
\hline \multirow[t]{2}{*}{ Average } & $(n=4)$ & +0.07 & 0.02 & This study \\
\hline & & +0.08 & 0.04 & Zeng et al. (2019) \\
\hline
\end{tabular}

a $2 \mathrm{SD}=$ two times the standard deviation of $\mathrm{n}$ repeat measurements.

$534{ }^{\mathrm{b}}$ Duplicate $=$ repeat column chemistry and measurement of different aliquots of a stock solution. 
537 Barium isotopic compositions and selected geochemical parameters of the natrocarbonatites and

538 silicate rocks from Oldoinyo Lengai (OL), Tanzania.

\begin{tabular}{|c|c|c|c|c|c|c|}
\hline Sample ID & Rock type & $\mathrm{Ba}(\mu \mathrm{g} / \mathrm{g})^{\mathrm{a}}$ & $\delta^{137 / 134} \mathrm{Ba}(\%$ o $)$ & $2 \mathrm{SD}(\% \mathrm{o})^{\mathrm{b}}$ & $\delta^{26} \mathrm{Mg}(\% \mathrm{o})^{\mathrm{c}}$ & $2 \mathrm{SD}(\% \mathrm{c})^{\mathrm{c}}$ \\
\hline \multicolumn{7}{|c|}{ OL carbonatites } \\
\hline OL2 & Natrocarbonatite & 13,430 & +0.03 & 0.03 & +0.31 & 0.08 \\
\hline OL7 & Natrocarbonatite & 14,330 & +0.03 & 0.03 & +0.37 & 0.10 \\
\hline OL123 & Natrocarbonatite & 11,280 & +0.01 & 0.03 & +0.19 & 0.10 \\
\hline Duplicate $^{\mathrm{d}}$ & & & +0.02 & 0.04 & & \\
\hline OL148 & Natrocarbonatite & 15,040 & +0.01 & 0.03 & +0.16 & 0.10 \\
\hline Duplicate & & & +0.01 & 0.04 & & \\
\hline OL259 & Natrocarbonatite & 13,790 & +0.03 & 0.03 & +0.13 & 0.10 \\
\hline
\end{tabular}

\section{OL silicate rocks not generated by liquid immiscibility}

$\begin{array}{cllllll}\text { OL247 } & \text { Nephelinite } & 1431 & +0.02 & 0.03 & -0.14 & 0.10 \\ \text { OL440 } & \text { Phonolite } & 1440 & +0.03 & 0.03 & -0.10 & 0.07 \\ \text { OL442 } & \text { Phonolite } & 1669 & +0.01 & 0.03 & -0.11 & 0.07 \\ \text { Duplicate } & & & +0.01 & 0.04 & & \\ \text { OL450 } & \text { Phonolite } & 1523 & +0.01 & 0.03 & -0.12 & 0.11 \\ \text { OL503 } & \text { Phonolite } & 1614 & +0.02 & 0.03 & -0.15 & 0.11 \\ \text { OL803 } & \text { Nephelinite } & 1612 & +0.02 & 0.03 & -0.13 & 0.10 \\ \text { Duplicate } & & & +0.02 & 0.04 & & \\ \text { OL822 } & \text { Phonolite } & 1532 & +0.03 & 0.03 & -0.25 & 0.09\end{array}$

OL silicate rocks related to the carbonatites by liquid immiscibility

\begin{tabular}{ccccccc} 
OL624 & Nephelinite & 1564 & +0.02 & 0.03 & -0.06 & 0.09 \\
OL788 & Nephelinite & 1970 & +0.01 & 0.03 & +0.07 & 0.11 \\
OL804 & Nephelinite & 2654 & +0.01 & 0.03 & +0.09 & 0.08 \\
Duplicate & & & +0.01 & 0.04 & & \\
\hline
\end{tabular}

539 a Data from Simonetti et al. (1997) and Klaudius and Keller (2006).

$540 \quad \mathrm{~b} 2 \mathrm{SD}=$ two times the standard deviation of $\mathrm{n}(\mathrm{n}>20)$ repeat measurements of the in-house reference solutions

541 during an analytical session.

$542 \quad$ c Data from Li et al. (2016).

$543 \mathrm{~d}$ Duplicate $=$ repeat column chemistry and measurement of different aliquots of a stock solution. 
546 Barium concentrations and isotopic compositions of carbonatites from Canada, East Africa,

547 Germany, and Greenland.

\begin{tabular}{|c|c|c|c|c|c|}
\hline Sample ID & Rock type & $\operatorname{Age}(\mathrm{Ma})^{\mathrm{a}}$ & $\mathrm{Ba}(\mu \mathrm{g} / \mathrm{g})^{\mathrm{a}}$ & $\delta^{137 / 134} \mathrm{Ba}(\%)$ & $2 \mathrm{SD}(\%)^{\mathrm{b}}$ \\
\hline \multicolumn{6}{|l|}{ Canada } \\
\hline DOD77 & Calcite carbonatite & 2680 & 985 & -0.03 & 0.04 \\
\hline DOD91 & Silicocarbonatite & 2680 & 806 & -0.07 & 0.04 \\
\hline Duplicate ${ }^{\mathrm{c}}$ & & & & -0.08 & 0.04 \\
\hline LSC20 & Calcite carbonatite & 2680 & 706 & +0.08 & 0.04 \\
\hline Duplicate & & & & +0.09 & 0.04 \\
\hline LSC108 & Calcite carbonatite & 2680 & 1472 & +0.09 & 0.04 \\
\hline Duplicate & & & & +0.09 & 0.04 \\
\hline \multicolumn{6}{|l|}{ East Africa } \\
\hline N1295 & Calcite carbonatite & 138 & 3920 & +0.02 & 0.04 \\
\hline PH212 & Calcite carbonatite & 116 & 452 & +0.05 & 0.04 \\
\hline PH213 & Calcite carbonatite & 116 & 530 & +0.04 & 0.04 \\
\hline SU103 & Calcite carbonatite & 40 & 366 & +0.05 & 0.04 \\
\hline DU365 & Ferrocarbonatite & 40 & 799 & +0.05 & 0.04 \\
\hline HB & Calcite carbonatite & 13 & 4454 & +0.01 & 0.04 \\
\hline \multicolumn{6}{|l|}{ Germany } \\
\hline K5 & Calcite carbonatite & 17 & 1319 & +0.03 & 0.04 \\
\hline \multicolumn{6}{|l|}{ Greenland } \\
\hline GR46 & Calcite carbonatite & 1300 & 405 & +0.05 & 0.04 \\
\hline GR73 & Calcite carbonatite & 1300 & 91 & +0.13 & 0.04 \\
\hline Duplicate & & & & +0.15 & 0.04 \\
\hline GR74 & Calcite carbonatite & 1300 & 66 & +0.22 & 0.03 \\
\hline Duplicate & & & & +0.23 & 0.03 \\
\hline
\end{tabular}

$548 \quad$ a Data from Halama et al. (2008) and references therein.

$549 \quad{ }^{b} 2 \mathrm{SD}=$ two times the standard deviation of $\mathrm{n}(\mathrm{n}>20)$ repeat measurements of the in-house reference solutions

550 during an analytical session.

$551 \quad{ }^{\mathrm{c}}$ Duplicate $=$ repeat column chemistry and measurement of different aliquots of a stock solution. 
552

553

554

555

556

557

558

559

560

561

562

563

564

565

566

567

568

569

570

571

572

573

\section{Figure captions}

Fig. 1. $\delta^{137 / 134} \mathrm{Ba}$ vs. Ba $(\mu \mathrm{g} / \mathrm{g})$ for carbonatites from Canada, East Africa (including Oldoinyo Lengai (OL)), Germany and Greenland. Data for silicate rocks from Oldoinyo Lengai are also shown. The gray area marks distribution of data from mid-ocean ridge basalts (MORBs) reported in Nielsen et al. (2018). The $\delta^{138 / 134} \mathrm{Ba}$ values reported in Nielsen et al. (2018) have been recalculated here to $\delta^{137 / 134} \mathrm{Ba}$ values, i.e. $\delta^{137 / 134} \mathrm{Ba}=0.75 \times \delta^{138 / 134} \mathrm{Ba}$ (Horner et al., 2015). Error bars represent 2SD uncertainties. Data are from Tables 2 and 3.

Fig. 2. (a) $\delta^{137 / 134} \mathrm{Ba}$ vs. $\delta^{26} \mathrm{Mg}$ for silicate rocks from Oldoinyo Lengai (OL); (b) $\delta^{137 / 134} \mathrm{Ba}$ vs. $\mathrm{CaO}(\mathrm{wt} \%)$ for carbonatites from OL. Data are from Table 2, and the $\mathrm{CaO}$ contents from Simonetti et al. (1997).

Fig. 3. (a) Histogram of $\delta^{137 / 134} \mathrm{Ba}$ values for carbonatites from Canada, East Africa (including Oldoinyo Lengai), Germany and Greenland. The red circles represent the three outliers identified using the box plot method (see NIST/SEMATECH e-Handbook of Statistical Methods). The gray band and vertical red line represent the range and estimated average $\delta^{137 / 134} \mathrm{Ba}$ value for the mantle sources of carbonatites (i.e., $+0.04 \pm 0.06 \%$, 2SD), excluding the three outliers. Data are from Tables 2 and 3. (b) Histogram of $\delta^{137 / 134}$ Ba values for MORBs (Nielsen et al., 2018). The black horizontal lines and red vertical lines respectively represent the range and the average of $\delta^{137 / 134} \mathrm{Ba}$ values for marine sediments (Bridgestock et al., 2018, 2019; 
574 Nielsen et al., 2018) and altered oceanic crust (AOC; Nielsen et al., 2018). The 575 published $\delta^{138 / 134} \mathrm{Ba}$ values have been recalculated here to $\delta^{137 / 134} \mathrm{Ba}$ values, i.e. $576 \quad \delta^{137 / 134} \mathrm{Ba}=0.75 \times \delta^{138 / 134} \mathrm{Ba}($ Horner et al., 2015). 


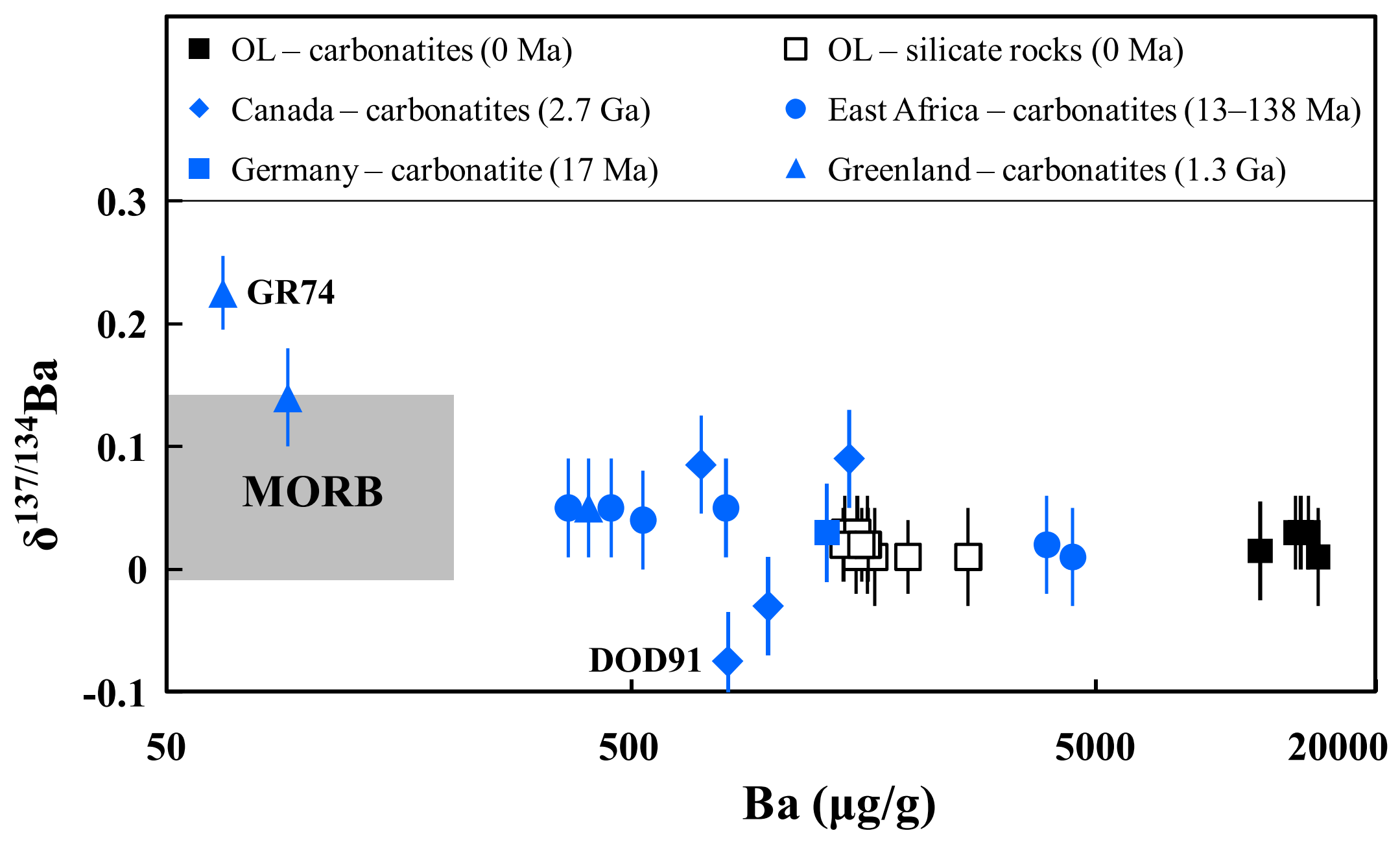

Fig. 1 


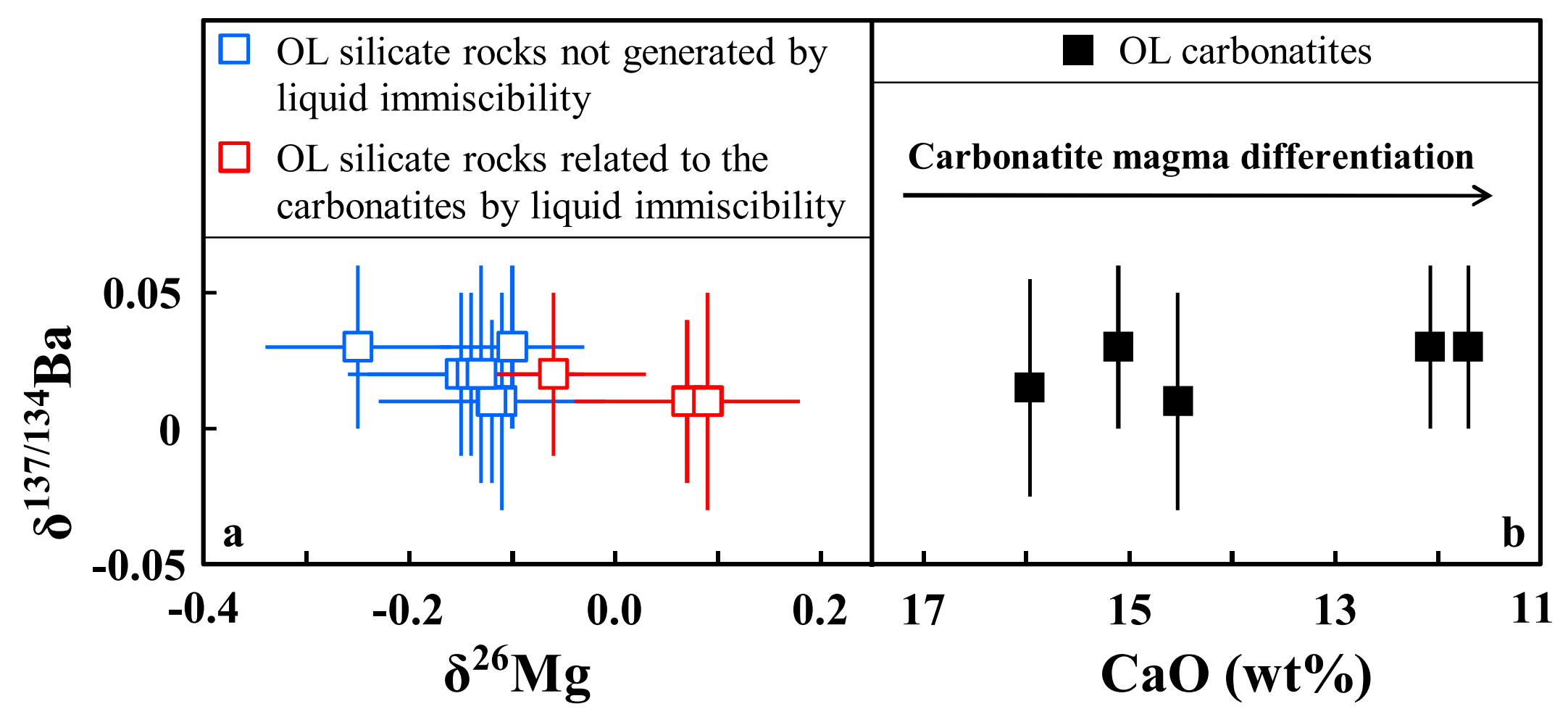

Fig. 2 

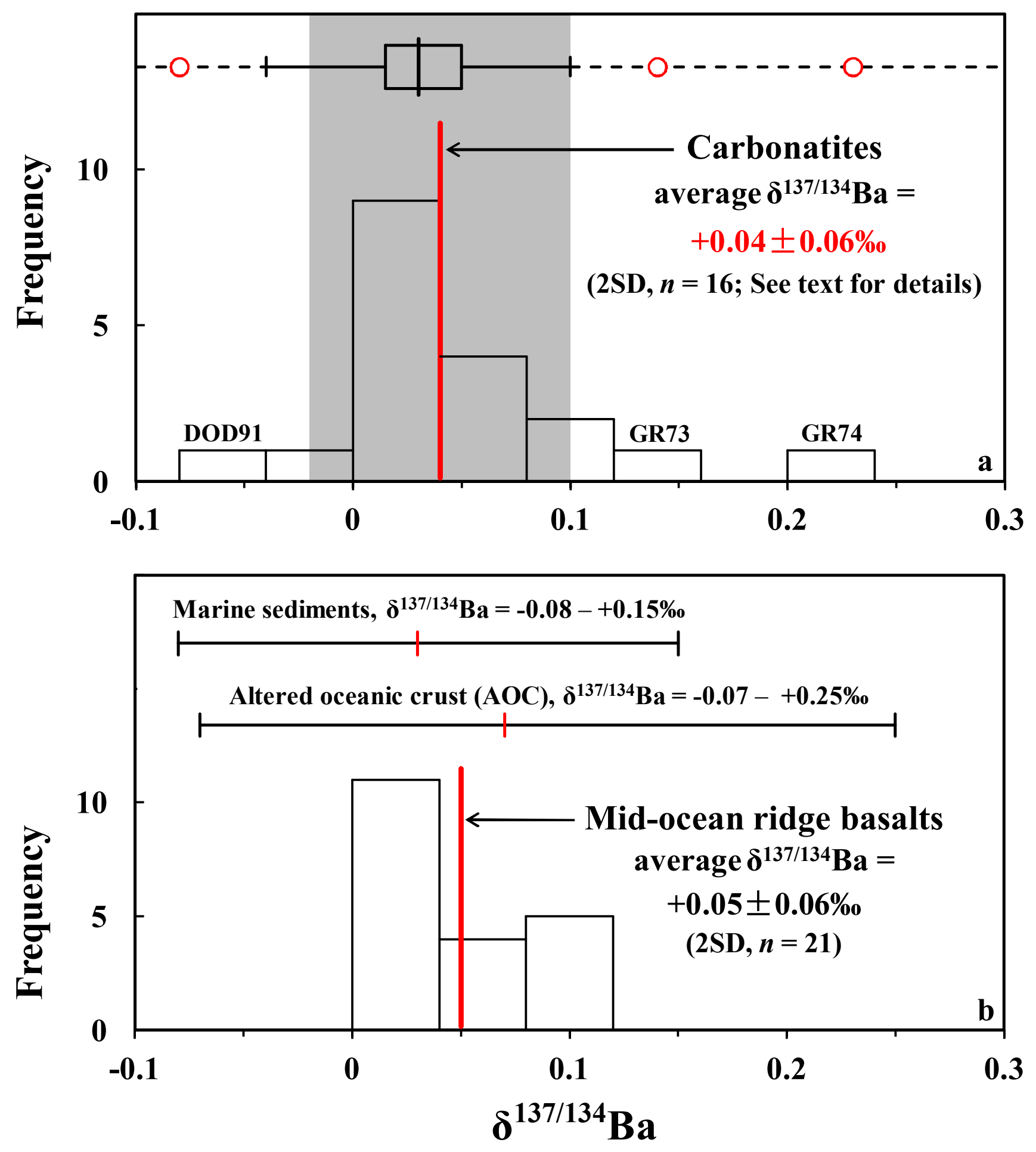

Fig. 3 